\title{
The 1990s Acceleration in Labor Productivity: Causes and Measurement
}

\author{
Richard G. Anderson and Kevin L. Kliesen
}

\begin{abstract}
The acceleration of labor productivity growth that began during the mid-1990s is the defining economic event of the past decade. A consensus has arisen among economists that the acceleration was caused by technological innovations that decreased the quality-adjusted prices of semiconductors and related information and communications technology (ICT) products, including digital computers. In sharp contrast to the previous 20 years, services-producing sectors-heavy users of ICT products-led the productivity increase, besting even a robust manufacturing sector. In this article, the authors survey the performance of the services-producing and goods-producing sectors and examine revisions to aggregate labor productivity data of the type commonly discussed by policymakers. The revisions, at times, were large enough to reverse preliminary conclusions regarding productivity growth slowdowns and accelerations. The unanticipated acceleration in the services sector and the large size of revisions to aggregate data combine to shed light on why economists were slow to recognize the productivity acceleration.
\end{abstract}

Federal Reserve Bank of St. Louis Review, May/June 2006, 88(3), pp. 181-202.

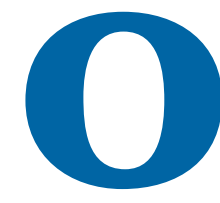

ver the past decade, economists have reached a consensus that (i) the trend rate of growth of labor productivity in the U.S. economy increased in the mid-1990s and (ii) the underlying cause of that increase was technological innovations in semiconductor manufacturing that increased the rate of decrease of semiconductor prices. ${ }^{1}$ This productivity acceleration is remarkable because, unlike most of its predecessors, it continued with only a minor slowdown during the most-recent recession. In this article, we briefly survey research on the genesis of the productivity rebound. We also examine the "recognition problem" that faced economists and policymakers during the 1990s when preliminary data, both economywide and at the industry

1 The first chapter of Jorgenson, Ho, and Stiroh (2005) surveys the decrease in semiconductor prices. level, showed little pick up in productivity growth. Using more than a decade of vintage "real-time" data, we find that revisions to labor productivity data have been large, in some cases so large as to fully reverse initial preliminary conclusions regarding productivity growth slowdowns and accelerations.

The 1990s acceleration of labor productivity has three important characteristics. First, it was unforeseen. An example of economists' typical projections during the mid-1990s is the 1996 Economic Report of the President, prepared during 1995, in which the Council of Economic Advisers foresaw no revolutionary change. The Council foresaw labor productivity growth in the private nonfarm business sector at an average annual rate of 1.2 percent from the third quarter of 1995 to the end of 2002. This estimate largely extrapolated recent experience: productivity from 1973 to 1995 had grown at an average annual rate of 1.4 percent.

Richard G. Anderson is an economist and vice president and Kevin L. Kliesen is an economist at the Federal Reserve Bank of St. Louis. The authors thank Aeimit Lakdawala, Tom Pollmann, Giang Ho, and Marcela Williams for research assistance.

(C) 2006, The Federal Reserve Bank of St. Louis. Articles may be reprinted, reproduced, published, distributed, displayed, and transmitted in their entirety if copyright notice, author name(s), and full citation are included. Abstracts, synopses, and other derivative works may be made only with prior written permission of the Federal Reserve Bank of St. Louis. 
Figure 1

\section{Nonfarm Labor Productivity}

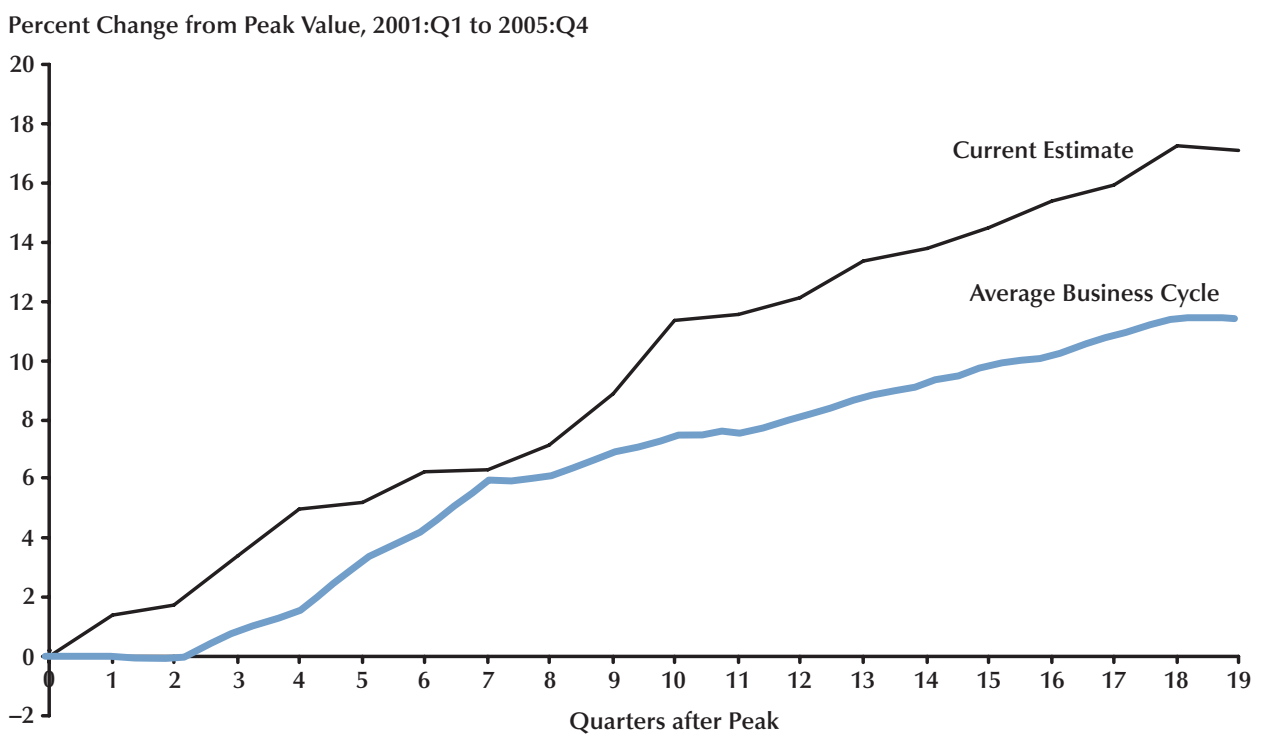

NOTE: The NBER's business cycle dating committee on November 26, 2001, selected the first quarter of 2001 as the cyclical peak. The business-cycle average is calculated as the mean of the nine NBER post-World War II business cycles, excluding the 1980 and 2001 recessions.

Incoming data during 1995 and 1996 were not signaling an increase in productivity growth. Gordon (2002, p. 245) notes that economists in 1997 were still seeking to identify the causes of the post-1973 slowdown in productivity growth: "Those of us who participated in panels on productivity issues at the January 1998 meetings of the American Economic Association recall no such recognition [of a productivity growth rate increase]. Rather, there was singular focus on explaining the long, dismal period of slow productivity growth dating from 1972."2 Today, with revised data, we know that the productivity acceleration started before 1995.

Labor productivity growth showed its resilience by slowing only modestly during the mild

2 As the discussion in Edge, Laubach, and Williams (2004) indicates, Princeton University professor Alan Blinder in 1997 estimated that future, near-term trend labor productivity growth was effectively the same as its average since 1974: 1.1 percent. Further, in 1999, Northwestern University professor Robert Gordon estimated a trend rate of growth of 1.85 percent; he then subsequently revised this up to 2.25 percent in 2000 and then to 2.5 percent in 2003 .
2001 recession. Forecasters adopted new views of the trend. By 2001, the Council of Economic Advisors had increased its projection of the annual growth of structural labor productivity to 2.3 percent per year. Other forecasters, including many in the Blue Chip Economic Indicators and the Federal Reserve Bank of Philadelphia's Survey of Professional Forecasters, were even more optimistic. ${ }^{3}$ Yet, since the March 2001 National Bureau of Economic Research (NBER) business cycle peak, labor productivity has been stronger than both these upward-revised forecasts and its average following past cyclical peaks; the latter point is illustrated in Figure 1. Although no one can be certain of future gains in productivity, it now seems clear that the combination of lower prices for information and communications technology (ICT) equipment plus new related business practices have boosted the economy's trend rate

\footnotetext{
3 See the September 10, 2000, issue of the Blue Chip Economic Indicators or the first quarter 2001 Survey of Professional
} Forecasters. 
of productivity growth. We note that similar increases in labor productivity growth have occurred in other eras and other countries, usually associated with technological innovations. ${ }^{4}$

Second, the underlying cause was an increase in the rate of decrease of semiconductor prices and, in turn, of ICT capital equipment. In response to falling ICT prices, producers in both servicesproducing and goods-producing sectors shifted increasing amounts of capital investment toward ICT products, reducing in some cases purchases of more traditional capital equipment. Subsequently, many business analysts have noted that, following a gestation lag, the lower cost of ICT equipment has induced firms to "make everything digital" and reorganize their business practices; Friedman (2005) and Cohen and Young (2005) provide detailed case studies.

And third, the post-1995 productivity acceleration is largely a services-producing sector story. ${ }^{5}$ After 1995, productivity growth in services increased sharply while productivity growth in manufacturing continued at approximately its then-extant pace. Ironically, the post-1973 slowdown in aggregate productivity growth also was a services-producing sector story-but one in which productivity in services-producing sectors collapsed. ${ }^{6}$ Post-1973 pessimists cited Baumol's

\footnotetext{
4 Basu et al. (2004) compare and contrast the differing U.S. and U.K. experiences after 1995.

5 In this article, we follow the Bureau of Economic Analysis (BEA) data reporting schema. Before June 2004, the BEA followed the SIC (Standard Industrial Classification) schema. Services-producing industries included transportation and public utilities; wholesale trade; retail trade; finance, insurance, and real estate (FIRE), including depository and nondepository institutions; and services (business services, including computer and data processing services). Private goods-producing industries included agriculture, forestry, and fishing; mining; construction; and manufacturing. In June 2004, the BEA revised its schema to follow the 1997 North American Industry Classification System (NAICS). The composition of services-producing industries changed slightly to include utilities; wholesale trade; retail trade; transportation and warehousing; finance, insurance, real estate, rental and leasing (FIRE); professional and business services, including computer systems design and related services; educational services, health care, and social assistance; arts, entertainment, recreation, accommodation, and food services; and other services, except government. Compared with the SIC, the NAICS more consistently classifies high-technology establishments into the correct industry and provides increased detail on the services sector (Yuskavage and Pho, 2004). We do not, in this analysis, examine interactions between these redefinitions and revisions to published data.

6 See Kozicki (1997).
}

(1967) analysis that services sectors had little potential to increase labor productivity and expounded views that the expanding share of services in gross domestic product (GDP) foreshadowed an eternal era of slow labor productivity growth for the U.S. economy. ${ }^{7}$ As early as the 1973 productivity slowdown, however, the servicesproducing sector was a major user of information technology, poised to benefit from improvements in semiconductor manufacturing. Hence, the significant technological advances in the early 1990s were especially important for services-producing sectors (Triplett and Bosworth, 2004; Jorgenson, Ho, and Stiroh, 2005). The mechanism was straightforward: Sharp decreases in the prices of semiconductors and related ICT capital goods induced services-sector firms to significantly increase their use of ICT capital, in turn increasing productivity growth and, with it, productivity growth for the entire economy. Both then and now, three-quarters of private-sector real GDP arises from services-producing sectors.

Poor data quality often has been cited as the barrier to identifying the causes of the post-1973 slowdown in services-sector productivity growth; see Griliches (1992 and 1994) or Sherwood (1994). Measurement issues for services-producing sectors have a long history, largely focused on correct measures of "output," including the price deflators necessary for obtaining real output from nominal magnitudes. As early as 1983, members of the Federal Open Market Committee (FOMC) questioned the quality of data on output and productivity in services-producing sectors; such discussions became longer and more frequent after Chairman Greenspan's lengthy soliloquy at the December 22, 1992, meeting. ${ }^{8}$ In 1996, Chairman Greenspan noted it was implausible that services-sector labor

\footnotetext{
7 Baumol (1967) argued that some services-including municipal government, education, performing arts, restaurants, and leisure time activities-had a "technological structure" that made longterm increases in the real cost of such services unavoidable because it was unlikely that productivity gains would be large enough to offset increasing wages. Baumol did not suggest, however, that all services-producing sectors were condemned to little or no productivity growth even though some later authors attributed that position to him.

8 Anderson and Kliesen (2005) review the history of productivity discussions in the FOMC transcripts from 1982 to 1999.
} 
productivity had not increased during the past 20 years and requested the Board staff to conduct a study of the quality of data for services-producing industries. The resulting study-Corrado and Slifman (1999)—confirmed the problematic quality of services-sector data but concluded that "the output, price, and unit-costs statistics for the nonfinancial corporate sector are internally consistent and economically plausible” (p. 332). ${ }^{9}$ Yet, even in these data, measured productivity growth in manufacturing was approximately double that in nonmanufacturing: For 1989 to 1997, the increases in output per hour were 2.9 and 1.4 percent for manufacturing and nonmanufacturing, respectively (Corrado and Slifman, 1999, p. 329, Table 1).

The situation has improved significantly in recent years. During the past decade, data measurement programs at both the BEA and the Bureau of Labor Statistics (BLS) have produced wellmeasured data for the services sectors, culminating in the BEA's December 2005 publication of the first NAICS industry-level data fully consistent across their input-output matrices, their annual industry accounts, and the nationwide GDP national income accounts system. Somewhat earlier, resolution of the vexing services-sector productivity problem occurred in 2000 when the BEA incorporated into the annual industry accounts their October 1999 revisions to the national income and product accounts (NIPA). ${ }^{10}$

9 Corrado and Slifman (1999) argued that most data problems were in the nonfinancial noncorporate sector, half of which was composed of difficult-to-measure services-sector firms. They concluded that mismeasurement so contaminated these figures that data for the nonfarm business sector should not be used for analysis.

${ }^{10}$ During the 1990s, the BEA greatly expanded and improved its industry database, partly in response to controversy regarding productivity growth. The BEA added gross output (shipments) by industry in 1996 (Yuskavage, 1996). Gross output is more desirable for productivity studies than gross product originating (value added), a point highlighted by Evsey Domar's much-earlier quip that few people find it interesting to study productivity in shoe manufacturing when leather is omitted. Interested readers can judge the impact of the October 1999 revisions by comparing studies before and after their publication. Such a comparison is not included here because, in our opinion, methodological changes for the annual industry accounts have been so large as to render comparisons of vintage data of questionable value. Typical of the pre-revision analyses is Triplett and Bosworth (2001), a paper originally presented at the January 2000 American Economic Association meetings. Ironically and with more than a touch of understatement, they note that "The nonfarm multifactor productivity numbers are due for revision in the near future, to incorporate the revisions to GDP that
Previously published data had shown some rebound in measured productivity growth for services sectors, but services continued to lag well behind manufacturing. The revised sector and industry data demonstrated that, far from being the laggard, labor productivity growth in servicesproducing sectors had exceeded productivity growth in manufacturing during the 1990s.

Two extensive recent analyses are Triplett and Bosworth (2004) and Jorgenson, Ho, and Stiroh (2005). Unfortunately, the studies' datasets and analytics differ, making direct comparisons of their numerical productivity growth rates difficult. ${ }^{11}$ For brevity, we cite results from only one of the studies. Triplett and Bosworth (2004) find that labor productivity in services-producing industries increased at an annual average rate of 2.6 percent between 1995 and 2001 (including the 2001 economic slowdown), slightly faster than manufacturing's 2.3 percent pace. Servicesproducing sectors accounted for 73 percent of 1995-2001 labor productivity growth and 76 percent of multifactor productivity growth (defined below). Increased use of ICT capital was the primary cause behind the productivity acceleration: When weighted by its large share of the economy, increased ICT use in services accounts for 80 percent of the total contribution of ICT to increased economywide labor productivity growth between 1995 and 2001. Their conclusion? On page 2, they write, "As with labor productivity growth and

were released in October, 1999. This will undoubtedly raise the nongoods estimate but not the manufacturing productivity estimate..." Shortly thereafter, they declared "Baumol's disease" to be cured; see Triplett and Bosworth (2003 and 2006), the latter paper was originally prepared for an April 2002 conference at Texas A\&M University. Interested readers might also compare Gordon (2000 and 2003). One of the earliest studies using the revised data is Stiroh (2002), which first appeared in January 2001 as Federal Reserve Bank of New York Staff Report 115 (the published article contains later, revised data) and showed productivity accelerations in broad service sectors, including wholesale and retail trade and finance, insurance, and real estate.

11 Triplett and Bosworth use output and employment data from the BEA's annual industry accounts and capital from the BLS's capital flow accounts. Their labor input measure is persons employed, not hours worked, and is not quality-adjusted. Although these shortcomings perhaps bias upward their estimated level of labor productivity, it seems unlikely that it distorts labor productivity growth significantly over shorter periods (i.e., 5 years or so). Jorgenson, Ho, and Stiroh measure output broadly to include the services of household durable goods and housing. They also use constant-quality index numbers for labor and capital input. 
multifactor productivity growth, the IT [information technology] revolution in the United States is a services industry story." It is important to note, as they do, that not all services-sector industries had productivity increases; most did, but some services industries continue to have negative measured productivity growth.

\section{THE ROLE OF SEMICONDUCTOR PRICES}

Understanding the sources of the labor productivity acceleration makes it easier to appreciate the difficulties in measuring it. Economists define labor productivity as the ratio of the economy's real output, $Y$, to total hours of labor input, $H, Y / H$. Let us assume that total output is produced by means of an aggregate production function, $Y=$ $A \times F(H, K)$, where $K$ measures the flow of productive services from the economy's capital stock and $A$ measures increases in output not due to increases in labor $(H)$ or capital $(K)$, that is, multifactor productivity (MFP). ${ }^{12}$ In this framework, there are two sources of increases in labor productivity: capital deepening and increases in MFP. Capital deepening is defined as increases in the amount of capital equipment available per hour worked, $K / H$. Increases in MFP often are referred to as improvements "in the ways of doing things," that is, changes in firms' business management practices. The growth rate of $A$ may be written as, and often is measured as, a residual by means of the equation

$$
g_{A}=g_{Y}-\left[(1-v) g_{K}+v g_{H}\right],
$$

where $g_{A}, g_{Y}, g_{K}$, and $g_{H}$, respectively, are the growth rates of MFP, output, capital services, and labor services and $v$ is the share of labor in total output. When increases in output, $Y$, are fully accounted for by increases in $H$ or $K$ by means of the function $F(H, K)$, then by definition there is no change in $A$, that is, no increase in MFP (but

\footnotetext{
${ }^{12}$ For simplicity, we are omitting intermediate inputs, making total output equal to value added (real GDP originating). For a richer model that contains intermediate inputs, see Jorgenson, Ho, and Stiroh (2005). The term $A$ also often is referred to as the Solow residual.
}

labor productivity may continue to increase through capital deepening).

Note that mismeasurement of $H$ or $K$ will cause mismeasurement of MFP. Specifically, if $H$ and $K$ contain unmeasured increases in quality, then measured $H$ and $K$ will tend to understate the flow of labor and capital services and tend to overstate growth of MFP. ${ }^{13}$ Productivity statistics published by the BLS use, for $H$, a constant-quality index of labor input that adjusts for such changes by using hourly wage rates to combine the working hours of workers with different characteristics. ${ }^{14}$ For the brief time periods considered here, labor quality adjustments likely matter little: For 1995-2000, Jorgenson, Ho, and Stiroh (2005) find that the difference between aggregate economywide hours at work and their constant-quality quantity index of labor volume is small. The constant-quality index grew only 0.34 percent faster than total hours worked during the period, largely due to the more rapid growth of higher-paid workers.

Measuring capital input, $K$, has similar issues. The productive capital stock of the United States is a heterogeneous collection of producers' durable equipment and structures, each with different specific characteristics. Although macroeconomists tend to measure the "capital stock" by summing the constant-dollar purchase prices of all such capital assets (after a depreciation allowance), a superior practice for productivity analysis is to measure $K$ as a constant-quality quantity index of the flow of capital services. ${ }^{15}$ Jorgenson, Ho, and

\footnotetext{
${ }^{13}$ This relationship has been well-known at least since Solow (1960). Note that Solow (1957) uses a capital stock measure that is not adjusted for quality change and, as a result, captures almost all productivity improvements in $A$ as MFP. Solow (2001) lauds the introduction of constant-quality labor and capital services index numbers. Many macroeconomic studies, however, continue to use capital stock measures unadjusted for quality; see, for example, Jones (2002).

${ }^{14}$ Jorgenson, Gollop, and Fraumeni (1987) is the classic study. For a recent discussion that also provides newly constructed measures for ICT-related sectors, see Jorgeonson, Ho, and Stiroh (2005, Chap. 6).

${ }^{15}$ Hulten (1992) has a clear exposition of the trade-off between measuring quality change in capital goods and measuring multifactor productivity. Pakko (2002a) explores whether applying reasonable quality adjustments to non-ICT capital investment during the 1990s would change the then-published profile of investment spending. He concludes it would not.
} 
Stiroh (2005) emphasize that incorporating quality measures for capital services is essential to understanding the 1990s productivity acceleration.

Many analysts have noted the short service lives, rapid depreciation rates, and high marginal products of ICT equipment. Further, the technological innovations that accelerated the fall in semiconductor prices have also allowed the creation of entirely new types of ICT capital goods (as well as innovative consumer goods). ${ }^{16}$ During the 1990s, for example, businesses shifted their capital investment spending patterns toward relatively shorter-lived ICT capital; information processing equipment and software comprised 25.1 percent of private fixed investment in 2002 versus 11.4 percent in 1977. Both Triplett and Bosworth (2004) and Jorgenson, Ho, and Stiroh (2005) use qualityadjusted capital stock data from the BLS constructed using methods pioneered by Jorgenson. To be specific, a constant-quality quantity index for investment in asset $j$ can be written as

$$
I_{j}=\frac{\text { Nominal Investment }_{j}}{P_{I, j}},
$$

where $P_{I, j}$ is a constant-quality price index that reflects changes in the productive characteristics and perceived "quality" of the capital asset (time subscripts are omitted). If $P_{I, j}$ is correct, then $I_{j}$ measures the quantity of new nominal investment in constant-quality "efficiency units" relative to the base year of the price index (Hulten, 1990). Capital stocks are constructed by means of these methods, for example, in Jorgenson, Ho, and Stiroh (2005, Chap. 5).

Solow (2001) emphasizes that constant-quality price and quantity indices are subtle concepts, as is the separation of capital deepening from MFP. Fundamentally, all productivity increases are due to increases in knowledge: In some cases, an economist might measure these as increases in quality-adjusted capital and capital deepening; in other cases the economist might identify the

\footnotetext{
${ }^{16}$ Innovations in communications equipment include cell phones, high-density multiplexers for fiber optic cable, and voice-overInternet-protocol (VOIP) telephone equipment. Doms (2005) provides a survey.
}

gains as MFP after quality adjustments have been made to labor and capital inputs. Regardless, increases in the knowledge of how to produce goods and services is the fundamental cause of productivity growth. Quality adjustments often are subjective and uncertain. Judgment errors in the $P_{I, j}$ necessarily affect measures of both capital deepening and MFP. Overestimates of increased quality potentially can inflate constant-quality quantity indices to the extent that MFP vanishes. Solow offers an example to illustrate the issue. Consider a competitive two-sector economy in which one sector produces capital goods from labor (only) and the other produces consumer goods from labor and capital. Let us assume a technological innovation occurs that reduces the quantity of labor required to produce one unit of the capital good but does not change its physical characteristics. In this case, both the observed market price and the constant-quality price index fall (no quality adjustment is made to the observed price of the capital good). As profit-maximizing producers of consumer goods increase the quantity of now less-expensive capital per hour of labor, both the physical capital stock and the constantquality quantity index (as well as the capitallabor ratio) will increase. Alternatively, starting from the same two-sector economy as before, let us assume a technological innovation occurs that increases the productivity of each unit of capital in the production of consumer goods but does not change the amount of labor required to produce each unit of the capital good. In this case, the observed price of the capital good is unchanged but the constant-quality price index for capital goods falls. As profit-maximizing producers of consumer goods replace older capital with newer capital, the constant-quality quantity index for capital will increase even if the physical capital stock does not, and the ratio of constant-quality capital units to labor volume will rise. Under mild assumptions, the long-run equilibrium economic effect of the two alternative technological innovations is exactly the same, although the adjustment may entail a long lag when the technological improvement is largely or entirely embedded in 
the new capital good (Pakko, 2002b and 2005). The widely used putty-clay model of Greenwood, Hercowitz, and Krussell (1997) is similar to Solow's example. In their model, a single output good can be "hardened" into consumption goods, investment in structures, or investment in equipment. The production function for output includes labor and both types of capital goods, allowing rich feedback effects among investment-specific technological progress, production of new capital goods, and capital deepening. ${ }^{17}$

Solow's example is helpful in understanding how investment in ICT equipment affects productivity. To be specific, it is useful to distinguish between increases in productivity at firms that make high-technology products and at firms that solely use ICT. ${ }^{18}$ For the former, technological progress in semiconductor manufacturing allows more computing power to be produced from the same inputs of capital and labor because such firms are large users of information technology equipment in development and production. For the latter, decreases in the cost of information technology induce capital deepening-that is, they induce the firm to provide additional capital equipment for each worker. Examples include initiating/expanding e-commerce on the Internet; improving the timeliness of linkages between point-of-sale cash registers and inventory management systems; and improving network links among geographically separated sites. Studies suggest that such changes in business practice may take considerable time to implement; hence, the response of productivity to changes in investment

\footnotetext{
${ }^{17}$ Greenwood, Hercowitz, and Krussell (1997) compare their constantquality capital stock measures for 1954-90, built from data as published circa early 1994, to the capital stock measures calculated by the BEA (which at that time lacked quality adjustment) but not to the constant-quality quantity indices of the BLS. See Dean and Harper (2001) and Jorgenson, Landefeld, and Nordhaus (2006) for comparisons of the BEA and BLS capital measures.

${ }^{18}$ Readers are cautioned that Solow's example, while illustrative, is only an example; recall he assumes that capital goods are made from labor only. In the real world, semiconductor manufacturing is a large user of its own products in the form of computer-assisted design and manufacturing. In the model of Greenwood, Hercowitz, and Krussell (1997), the economy's output can be hardened into capital which, in following periods, is an input to the production of more output, including future capital goods.
}

in ICT equipment varies among firms and industries. Such variation may delay timely recognition that forces have arisen, which, eventually, will increase productivity economywide.

\section{EMPIRICAL ESTIMATES OF ACCELERATING AGGREGATE LABOR PRODUCTIVITY}

The above framework has been used by a number of authors to measure the effect of investment in ICT on productivity growth. Among the more important aggregate (not industry-level) studies are Oliner and Sichel (2002) and Jorgenson, Ho, and Stiroh (2002, 2003, and 2004). Although the studies' details differ, at the aggregate level of the national economy the authors attribute approximately three-fifths of the acceleration in labor productivity during the second half of the 1990s to capital deepening and two-fifths to increases in MFP. In turn, the authors find that approximately four-fifths of the capital deepening is due to investment in ICT equipment, with increased spending on traditional business equipment accounting for the other one-fifth. Both studies emphasize that purchases of ICT equipment were boosted by rapid decreases in the prices of such equipment, due in large part to rapidly falling prices of component semiconductors, and perhaps displaced to some extent purchases of traditional equipment.

As an example of the interaction between measurement and economic modeling, consider the Oliner and Sichel (2002) model. In this model, the rate of increase in MFP is measured by the inverse of the rate of decrease of semiconductor prices, creating a direct link between observed decreases in semiconductor prices and unobserved increases in productivity growth. The intuition is that, because semiconductor prices are falling rapidly relative to the aggregate price level, MFP at semiconductor manufacturers must be increasing; if not, the firms would exit the industry. The effect of this measurement technique is that the sharp decline in semiconductor prices in 1997, shown in Figure 2, appears immediately as an 
Figure 2

\section{Contributions to Labor Productivity Growth and Relative Changes in Semiconductor Prices}

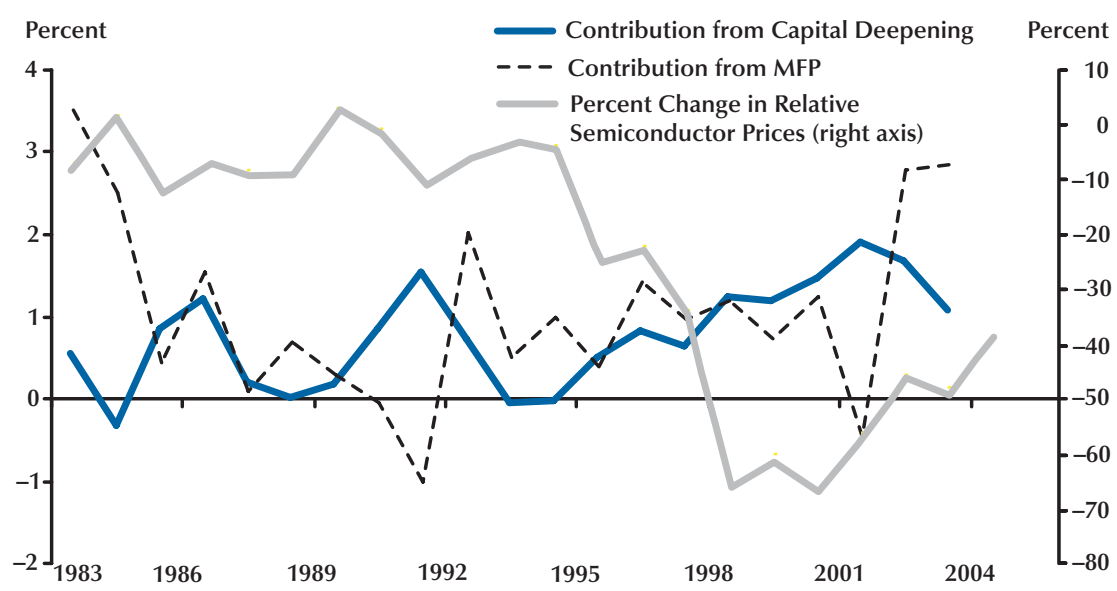

SOURCE: Productivity data, Dan Sichel (via e-mail); semiconductor prices, BLS.

increase in labor productivity growth. More recent estimates provided to the authors by Dan Sichel, shown in Figure 2, suggest that the direct contribution from the semiconductor industry was responsible for 0.08 percentage points of the 0.37 percent growth of MFP from 1974 to 1990 and 0.13 percentage points of the 0.58 percent growth from 1991 to 1995; after 1995, the proportions change.${ }^{19}$ He estimates that the direct contribution from the semiconductor industry from 1996 to 2003 was responsible for 0.40 percentage points of the economy's total 1.34 percent annual growth of MFP.

Complementary analyses are presented by Jorgenson, Ho, and Stiroh (2002 and 2004). (The latter paper's results differ from the former's because of data revisions.) In their 2004 analysis, labor productivity (adjusted for shifts in labor quality) increased during the $1995-2003$ period at a rate 1.6 percentage points greater than during the 1973-95 period; they attribute a little less than three-fifths of this increase to capital deepening.

If the acceleration of productivity was driven by an increase in the rate of decrease of semicon-

${ }^{19}$ Unpublished estimates received from Dan Sichel via e-mail correspondence on June 28, 2004. ductor (and computer) prices, just how fast did prices fall? As shown in Figure 2, semiconductor prices decreased throughout the 1990s with the rate of decrease accelerating during the latter half of the decade. Caution must be used in interpreting these figures, however, because rapid technological change has introduced thorny quality-adjustment problems. The caution expressed by Gullickson and Harper (2002) is typical:

These findings rest on estimated trends for high tech inputs and outputs that incorporate adjustments to account for changes in their quality. Many of the high tech input and output growth rates are well up in the double-digit percentage range. These extraordinary trends, in turn, rest on the use of quality adjusted price indexes in deflation. These indicate that prices for high tech goods of constant quality have fallen very rapidly. These price trend estimates have withstood much scrutiny, but we must emphasize their importance for our conclusions. While it is likely that real output trends have been underestimated in many or all of the service sector industries with negative MFP trends, it is also possible that the growth trends for high tech inputs have been overestimated. Underestimating service sector output trends would bias the aggregate productivity trend down- 
ward. Overestimating high tech input and output trends would bias the aggregate productivity trend upward...We can express a concern that the "measurement playing field" may not be level. We have very intricate means of making quality adjustments to high tech goods, but we have few means to make quality adjustments to service outputs.

In other cases, the survey sample for some products, such as semiconductors, has changed. ${ }^{20}$ Holdway (2001, p. 15), cautions:

It would be disingenuous to imply that the PPI has been able to properly value and account for technological change in its cmpu [CPU] price measurements. The standard PPI methodologies for valuing quality change [are] rather limited when faced with quality improvements that are accompanied by reduced input costs due to shifts in the production function.

Holdway also notes that the apparent acceleration of semiconductor price decreases during early 1997, as shown in Figure 2, most likely is a result of the introduction of secondary-source pricing data. ${ }^{21}$ Interested readers also should see Grimm (1998) and Landefeld and Grimm (2000). Since 2000, the relative price of quality-adjusted semiconductors (and related products) has decreased at a slower rate than during the latter part of the 1990s; see Figure 2. Even though the relative prices of semiconductors fell by approximately 38 percent in 2004, this was less than its average decline of approximately 65 percent from 1998 to 2000.

\footnotetext{
${ }^{20}$ For semiconductor prices, for example, the BLS has a series in the producer price index, the BEA has a series used in the national income accounts, and the Federal Reserve Board has a price measure used in its industrial production index. See, for example, Hulten (2001). The semiconductor price series plotted in Figure 7 is the PPI measure relative to the GDP price index.

${ }^{21}$ Secondary source prices are price figures collected from catalogs and industry publications, rather than from the manufacturer's price list. Holdway doesn't speculate on whether secondary-source price data, if available, might change the pre-1997 trend, but the absence of such data introduces a risk into any study that attributes the productivity acceleration to more rapid price decreases: Would the studies reach the same conclusion if the rate of price decrease from 1993 to 1997 had been the same as that beginning in 1997? Or did the decision to solicit secondary-source price data reflect observations of increased pricing pressure?
}

\section{LABOR PRODUCTIVITY: MEASUREMENT, VOLATILITY, AND REVISIONS}

Published labor productivity growth rates have two characteristics that complicate recognizing changes in trend growth: volatility and revisions. Volatility is illustrated in Figure 3, which shows compound annual growth rates calculated from the most recently published data for 1-, 4-, and 40-quarter intervals. The high volatility is obvious. Beyond volatility, the figure also illustrates that "trend" labor productivity growth since World War II appears to have gone through three phases: more rapid growth from 1948 to 1973; slower growth from 1973 to 1994; and more rapid growth beginning circa 1995. Measured labor productivity growth in the nonfarm business sector, for example, averaged 3 percent per annum during 1949 to 1972 but less than half this pace during 1973 to 1994, despite strong productivity growth in manufacturing.

Since 1995, the pace of productivity growth in the total nonfarm business sector has been about equal to its rate during the earlier high-growth period of 1949 to 1972; for the larger total private business sector, growth over the past 10 years still remains modestly below its earlier pace. The lower two sections of Table 1 decompose productivity growth into growth of its numerator (output) and of its denominator (hours). The increase in productivity growth from 1973-94 (column 2) to 19952004 (column 3) reflects both more rapid growth of the numerator (output) and slower growth of the denominator (hours). For broad sectors, the table shows that the post-1973 productivity growth slowdown (compare columns 1 and 2) largely was due to slowdowns in the services and nondurable manufacturing sectors-durable manufacturing's labor productivity growth increased modestly throughout the slowdown period. During the most recent decade, durable manufacturing's productivity growth has jumped to an average annual pace of approximately 5.75 percent, double its 1949-72 pace.

Published measurements of the economy's output and labor input are frequently revised. Not only do data revisions complicate the task facing 
Figure 3

\section{Labor Productivity Growth, Nonfarm Business Sector}

10-Year Growth Rate

Compound Annual Rate, Percent, Quarterly Data

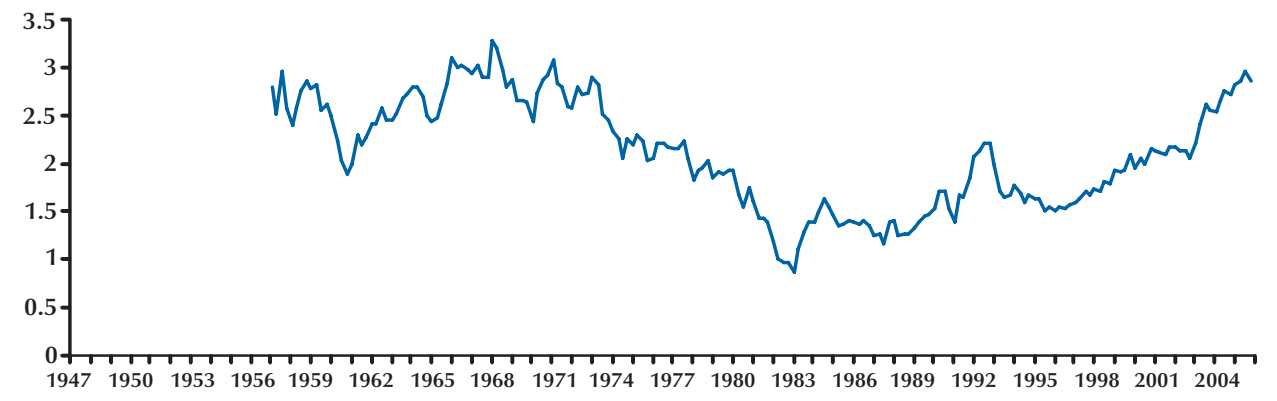

1-Year Growth Rate

Compound Annual Rate, Percent, Quarterly Data

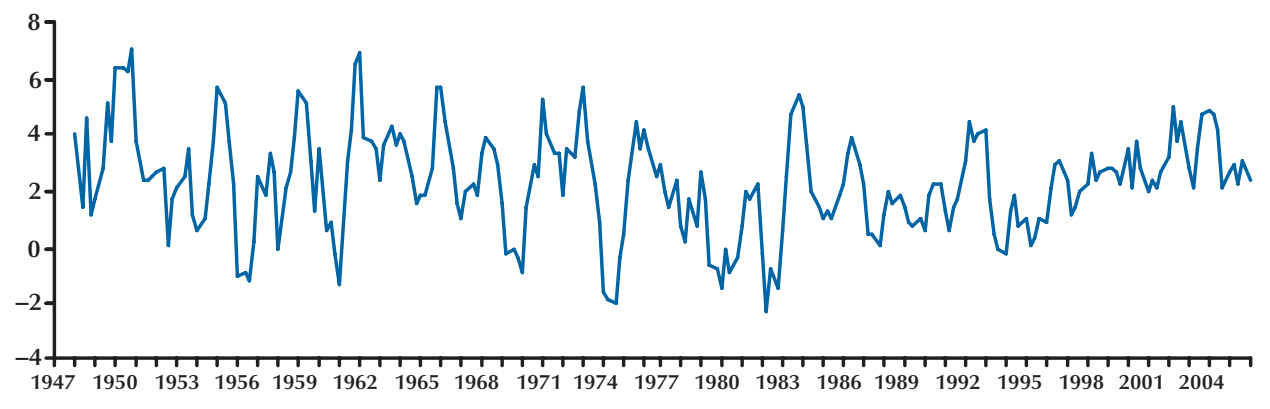

\section{1-Quarter Growth Rate}

Compound Annual Rate, Percent, Quarterly Data

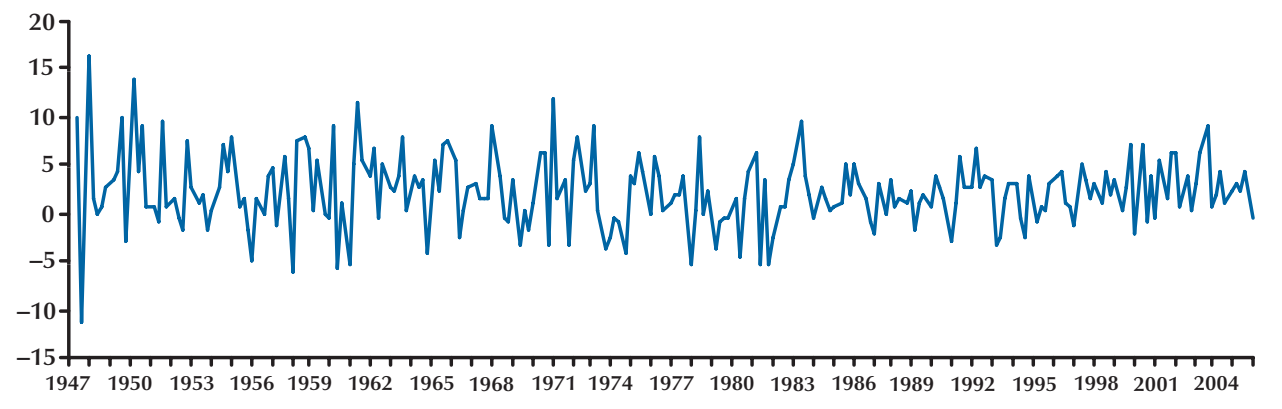




\section{Table 1}

\section{Decomposition of Average Labor Productivity Growth for the Business Sector}

\begin{tabular}{|c|c|c|c|c|}
\hline & \multicolumn{4}{|c|}{ Growth for periods indicated } \\
\hline & 1949-72 & $1973-94$ & $1995-2005$ & 1949-2005 \\
\hline \multicolumn{5}{|l|}{ Output per hour } \\
\hline Business & 3.23 & 1.58 & 2.76 & 2.49 \\
\hline Nonfarm business & 2.77 & 1.48 & 2.69 & 2.25 \\
\hline Manufacturing & 2.58 & 2.59 & 4.44 & 2.94 \\
\hline Durable & 2.64 & 3.02 & 5.86 & 3.40 \\
\hline Nondurable & 2.83 & 1.90 & 2.85 & 2.47 \\
\hline Nonfinancial corporate business & 2.61 & 1.40 & 3.34 & 2.21 \\
\hline \multicolumn{5}{|l|}{ Output } \\
\hline Business & 4.10 & 3.18 & 3.61 & 3.65 \\
\hline Nonfarm business & 4.22 & 3.17 & 3.64 & 3.70 \\
\hline Manufacturing & 3.74 & 2.51 & 2.38 & 3.00 \\
\hline Durable & 4.21 & 2.87 & 4.19 & 3.68 \\
\hline Nondurable & 3.48 & 1.90 & 0.16 & 2.22 \\
\hline Nonfinancial corporate business & 5.51 & 3.23 & 4.27 & 4.17 \\
\hline \multicolumn{5}{|l|}{ Hours } \\
\hline Business & 0.84 & 1.57 & 0.83 & 1.12 \\
\hline Nonfarm business & 1.41 & 1.66 & 0.92 & 1.41 \\
\hline Manufacturing & 1.14 & -0.08 & -1.97 & 0.05 \\
\hline Durable & 1.53 & -0.15 & -1.58 & 0.27 \\
\hline Nondurable & 0.63 & 0.00 & -2.61 & -0.25 \\
\hline Nonfinancial corporate business & 2.86 & 1.81 & 0.90 & 1.92 \\
\hline
\end{tabular}

NOTE: Compounded annual growth rates using quarterly data: 1949:Q1 to 1972:Q4; 1972:Q4 to 1994:Q4; 1994:Q4 to 2005:Q4. Data for nonfinancial corporations begins in 1958:Q1 and ends in 2005:Q3. Data for total manufacturing and durable and nondurable manufacturing are on an SIC basis prior to 1987. Data for total manufacturing and durable and nondurable manufacturing are on an SIC basis prior to 1987.

SOURCE: BLS.

policymakers-changing perceived strength or weakness of economic conditions that inform their judgments—but they are often significant enough to dramatically alter economic history. ${ }^{22}$ As an example, each year the BEA revises the national income and product accounts and the BLS revises employment and aggregate hours worked in the establishment survey. Selected revisions, and their effects, are shown in Table 2. For 1998 and 1999, for example, measured output growth in the sub-

${ }^{22}$ See Himmelberg et al. (2004), Kozicki (2004), Orphanides and van Norden (2005), or Runkle (1998). sequent, revised data is sharply higher than in the earlier, preliminary data. ${ }^{23}$ Beginning with 2001, however, the pattern changed: Measured output growth in the revised data has tended to be lower than in previous, preliminary figures. The NIPA revisions published during mid-2005, for example, trimmed measured real GDP growth over the previous three years by 0.3 percentage points per year, to approximately 3.25 percent.

23 The 1999 revisions, it should be noted, were boosted by the reclassification of software purchased by businesses as fixed investment, rather than as an intermediate expense; see Gullickson and Harper (2002). 
Table 2

Major Statistical Revisions Since 1996 and Real-Time Estimates of Their Effects

\begin{tabular}{|c|c|c|c|}
\hline Publication date & Statistical series & Major aspects of revision & $\begin{array}{c}\text { Estimated } \\
\text { magnitude of revision }\end{array}$ \\
\hline January 1996 & $\begin{array}{l}\text { Comprehensive revision } \\
\text { of the NIPA }\end{array}$ & $\begin{array}{l}\text { Switch to chain-weighted price } \\
\text { indices from fixed-weighted } \\
\text { price indices in the NIPA. } \\
\text { Government investment defined } \\
\text { differently. New methodology for } \\
\text { calculating depreciation of fixed } \\
\text { capital. }\end{array}$ & $\begin{array}{l}\text { Revised estimates show real GDP } \\
\text { grew at a } 3.2 \text { percent annual } \\
\text { rate from } 1959 \text { to } 1984,0.2 \\
\text { percentage points faster than } \\
\text { old estimate. Real GDP growth } \\
\text { from } 1987 \text { to } 1994 \text { was lowered } \\
0.1 \text { percentage point.* }\end{array}$ \\
\hline July 1998 & $\begin{array}{l}\text { Annual revision of the } \\
\text { NIPA }\end{array}$ & $\begin{array}{l}\text { Updated source data. Methodology } \\
\text { changes to expenditures and } \\
\text { prices for autos and trucks; } \\
\text { improved estimates for several } \\
\text { categories of consumer } \\
\text { expenditures for services; new } \\
\text { method of calculating change in } \\
\text { business inventories; some } \\
\text { purchases of software by } \\
\text { businesses classified as expenses } \\
\text { (removed from business fixed } \\
\text { investment). }\end{array}$ & $\begin{array}{l}\text { From 1994:Q4 to 1998:Q1 the } \\
\text { growth of real GDP was revised } \\
0.3 \text { percentage points higher to } \\
\text { 3.4 percent; growth of real fixed } \\
\text { investment revised } 0.6 \\
\text { percentage points higher to } 12.7 \\
\text { percent; growth of GDP price } \\
\text { index reduced } 0.3 \text { percentage } \\
\text { points to } 1.8 \text { percent. }\end{array}$ \\
\hline February 1999 & Consumer price index (CPI) & $\begin{array}{l}\text { Switch to geometric means } \\
\text { estimation to eliminate lower- } \\
\text { level bias; affected } 61 \text { percent of } \\
\text { consumer expenditures. }\end{array}$ & $\begin{array}{l}\text { According to the BLS, this switch } \\
\text { will reduce the annual rate of } \\
\text { increase of the CPI by } 0.2 \\
\text { percentage points per year. } \\
\text { According to the CEA, } \\
\text { methodological changes to the } \\
\text { CPI from } 1994 \text { to } 1999 \text { reduced } \\
\text { the annual rate of increase of } \\
\text { the CPI by } 0.6 \text { percentage } \\
\text { points in } 1999 \text { compared with } \\
\text { the } 1994 \text { estimate. }\end{array}$ \\
\hline October 1999 & $\begin{array}{l}\text { Comprehensive revision } \\
\text { of the NIPA }\end{array}$ & $\begin{array}{l}\text { Introduction of CPI geometric } \\
\text { weights; classification of } \\
\text { software as a fixed investment; } \\
\text { incorporated data from the } \\
\text { latest } 5 \text {-year economic census } \\
\text { and } 1992 \text { benchmark input-output } \\
\text { accounts. }\end{array}$ & $\begin{array}{l}\text { From } 1987 \text { to } 1998 \text {, these revisions } \\
\text { boosted the annual rate of } \\
\text { growth of real GDP by an } \\
\text { average of } 0.4 \text { percentage points } \\
\text { per year. } \neq\end{array}$ \\
\hline July 2001 & $\begin{array}{l}\text { Annual revision of the } \\
\text { NIPA }\end{array}$ & $\begin{array}{l}\text { Updated source data (for example, } \\
\text { Census Bureau Annual Surveys); } \\
\text { new price index for } \\
\text { communications equipment from } \\
\text { Federal Reserve Board; monthly } \\
\text { data used to calculate GDP } \\
\text { converted from SIC to NAICS. }\end{array}$ & $\begin{array}{l}\text { Growth of real GDP during } \\
\text { revision period (1998:Q1 to } \\
\text { 2001:Q1) reduced from } 4.1 \\
\text { percent to } 3.8 \text { percent } \\
\text { (compared with pre-revision } \\
\text { estimates). }\end{array}$ \\
\hline
\end{tabular}


Table 2, cont'd

Major Statistical Revisions Since 1996 and Real-Time Estimates of Their Effects

\begin{tabular}{|c|c|c|c|}
\hline Publication date & Statistical series & Major aspects of revision & $\begin{array}{c}\text { Estimated } \\
\text { magnitude of revision }\end{array}$ \\
\hline July 2002 & $\begin{array}{l}\text { Annual revision to the } \\
\text { NIPA }\end{array}$ & $\begin{array}{l}\text { Updated source data (for example, } \\
\text { Census Bureau annual surveys); } \\
\text { new methodology for estimating } \\
\text { quarterly wages and salaries; new } \\
\text { price index within PCE services. }\end{array}$ & $\begin{array}{l}\text { Growth of real GDP during } \\
\text { revision period (1999:Q1 to } \\
\text { 2002:Q1) reduced from } 2.8 \\
\text { percent to } 2.4 \text { percent } \\
\text { (compared with pre-revision } \\
\text { estimates). }\end{array}$ \\
\hline July 2004 & $\begin{array}{l}\text { Annual revision to the } \\
\text { NIPA }\end{array}$ & $\begin{array}{l}\text { Update source data; only minor } \\
\text { changes in methodology for } \\
\text { treatment of health care plans } \\
\text { for retired military and } \\
\text { measurement of motor vehicle } \\
\text { inventories. }\end{array}$ & $\begin{array}{l}\text { Growth of real GDP during } \\
\text { revision period (2000:Q4 to } \\
\text { 2004:Q1) was unchanged at } 2.5 \\
\text { percent; growth of real fixed } \\
\text { investment in equipment and } \\
\text { software revised } 0.6 \text { percentage } \\
\text { points lower. }\end{array}$ \\
\hline July 2005 & $\begin{array}{l}\text { Annual revision to the } \\
\text { NIPA }\end{array}$ & $\begin{array}{l}\text { Updated source data; incorporation } \\
\text { of Census' quarterly services } \\
\text { survey for investment in } \\
\text { computer software and for } \\
\text { consumer spending for services; } \\
\text { improved method of calculating } \\
\text { implicit services provided by } \\
\text { commercial banks. BEA claims }\end{array}$ & $\begin{array}{l}\text { Growth of real GDP from 2001:Q4 } \\
\text { to 2005:Q1 reduced from 3.5 } \\
\text { percent to } 3.2 \text { percent. Over the } \\
\text { same period, growth of GPD } \\
\text { price index and the core PCE } \\
\text { price index were revised } 0.2 \\
\text { percentage points higher to } 2.2 \\
\text { and } 1.7 \text { percent, respectively. }\end{array}$ \\
\hline
\end{tabular}

these changes will reduce the

volatility of the price index for PCE.

NOTE: Discussion and estimates of annual revisions to the NIPA were taken from archived reports at their web site: www.bea.gov.

SOURCE: *1996 Economic Report of the President, p. 48.

+2000 Economic Report of the President, p. 61.

flbid, p. 81.

Revisions to national income data change measured productivity, often significantly. Changes since 1994 are summarized in Table $3 .^{24}$ Consistent with revisions to output, in both 1998 and 1999 the BLS revised upward measured nonfarm labor productivity, and in 2001 and 2002 it revised downward measured productivity. The 2001 revision, for example, reduced the measured three-year growth rate of labor productivity by more than three-quarters of a percentage point. Overall, revisions to productivity growth primarily are due to revisions to measured output and not to revisions in measured employment or aggregate

\footnotetext{
${ }^{24}$ These revisions incorporate both the annual three-year revisions to the NIPA as well as the periodic comprehensive revisions, which occur about every five years. See the footnote to Table 3.
}

hours worked. Since 1994, for example, the mean absolute revision to the growth rate of output, 0.30 percentage points, is more than double that of hours worked, 0.14 percentage points, and approximately equal to that of the growth rate of productivity growth, 0.28 percentage points. ${ }^{25}$

A longer-horizon picture of historical revisions to measured labor productivity growth is shown in Figure 4. For each year, 1959 to 2004, the figure has one vertical line that summarizes all the values of that year's labor growth as published in various issues of the Economic Report of the President.

\footnotetext{
${ }^{25}$ The BLS's annual benchmark revisions to establishment data have become smaller over time. From 1984 to 2004, the absolute percentage change in nonfarm payrolls averaged 0.2 percent, a third as much as the 1964-83 period. See Haltom, Mitchell, and Tallman (2005).
} 
Table 3 Effect of Annual NIPA Revisions on Measured Growth of Labor Productivity, Output, and Hours
in the Nonfarm Business Sector (percent change at a compound rate)

\begin{tabular}{|c|c|c|c|c|c|c|c|c|c|}
\hline \multirow[b]{2}{*}{ NIPA revision period } & \multicolumn{3}{|c|}{ Output per hour } & \multicolumn{3}{|c|}{ Output } & \multicolumn{3}{|c|}{ Hours } \\
\hline & Initial & Revised & Difference & Initial & Revised & Difference & Initial & Revised & Difference \\
\hline 1994 & 2.55 & 2.36 & -0.19 & 3.99 & 4.12 & 0.13 & 1.40 & 1.70 & 0.30 \\
\hline 1995 & 1.72 & 1.68 & -0.04 & 4.70 & 4.85 & 0.15 & 2.87 & 3.09 & 0.22 \\
\hline 1996 & 0.83 & 0.57 & -0.26 & 2.92 & 2.84 & -0.08 & 2.03 & 2.28 & 0.25 \\
\hline 1997 & 0.75 & 0.88 & 0.13 & 3.21 & 3.33 & 0.12 & 2.40 & 2.44 & 0.04 \\
\hline 1998 & 1.55 & 2.06 & 0.51 & 4.15 & 4.76 & 0.61 & 2.60 & 2.64 & 0.04 \\
\hline 1999 & 2.31 & 2.60 & 0.29 & 4.44 & 4.74 & 0.30 & 2.38 & 2.42 & 0.04 \\
\hline 2000 & 3.30 & 3.30 & 0.00 & 5.41 & 5.51 & 0.10 & 2.06 & 2.13 & 0.07 \\
\hline 2001 & 3.05 & 2.28 & -0.77 & 4.28 & 3.60 & -0.68 & 1.16 & 1.27 & 0.11 \\
\hline 2002 & 3.08 & 2.71 & -0.37 & 2.00 & 1.44 & -0.56 & -1.08 & -1.27 & -0.19 \\
\hline 2003 & 2.87 & 3.60 & 0.73 & 1.56 & 1.50 & -0.06 & -1.27 & -2.02 & -0.75 \\
\hline 2004 & 4.69 & 4.45 & -0.24 & 4.33 & 4.23 & -0.10 & -0.38 & -0.23 & 0.15 \\
\hline 2005 & 3.97 & 3.68 & -0.29 & 4.76 & 4.59 & 0.17 & 0.76 & 0.87 & 0.11 \\
\hline Mean revision & & & -0.04 & & & 0.01 & & & 0.03 \\
\hline $\begin{array}{l}\text { Mean absolute } \\
\text { revision }\end{array}$ & & & 0.32 & & & 0.26 & & & 0.19 \\
\hline
\end{tabular}

NOTE: Pre- and post-benchmark figures as published in the BLS Productivity and Cost Report. The NIPA revision period is the nine quarters up to and including the first quarter of the year indicated. The year indicated is the year of publication of the NIPA revision, usually July or August. The 1999 NIPA revision, more extensive than most, incorporated the October 28, 1999, introduction of computer software into business fixed investment. This resulted in revisions back to 1959. Nevertheless, for consistency, the revisions shown here are for the nine quarters ending in the first quarter of the year indicated. (The 1999 revisions to "hours" appeared in the August 5, 1999, Productivity and Cost Report.)

The lower and upper ends of each line correspond to the lowest and highest published growth rates, respectively, for that year, while the "dot" indicates the most recent estimate. For many years, the minimum-to-maximum range equals or exceeds 2 percentage points. Ranges for years after 1995 are smaller, perhaps due to better measurement techniques, or perhaps because there are fewer observations.

Further insight can be gained from "case studies" of periods during which breaks in trend productivity growth occurred. Here, we consider 1973 and 1995-96.

- For 1973, the first-published estimate of labor productivity growth was approximately 3 percent; see Figure 5. This value fell sharply in subsequent revisions. During the late 1980s, however, the published value began to increase. In the most recently published data, 1973's measured productivity growth is greater than its initially published value-removing entirely any "slowdown" during the year. ${ }^{26}$

- For 1995 and 1996, the most recently published values differ sharply from initial estimates. For 1995, the most recent value is much lower than the initial estimate; see Figure 6. For 1996, the most recent figure is much higher than the initial estimate; see

\footnotetext{
${ }^{26}$ In this vein, it appears that the switch to chain weights from fixed weights in 1996 (see Table 2) was particularly significant. See Gullickson and Harper (2002).
} 


\section{Figure 4}

\section{Revisions to Real-Time Estimates of Labor Productivity Growth, 1959-2004}

1959-69

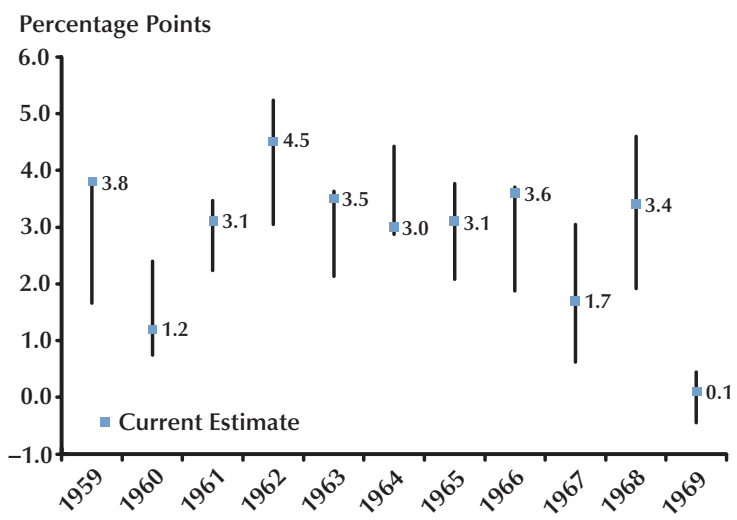

1980-89

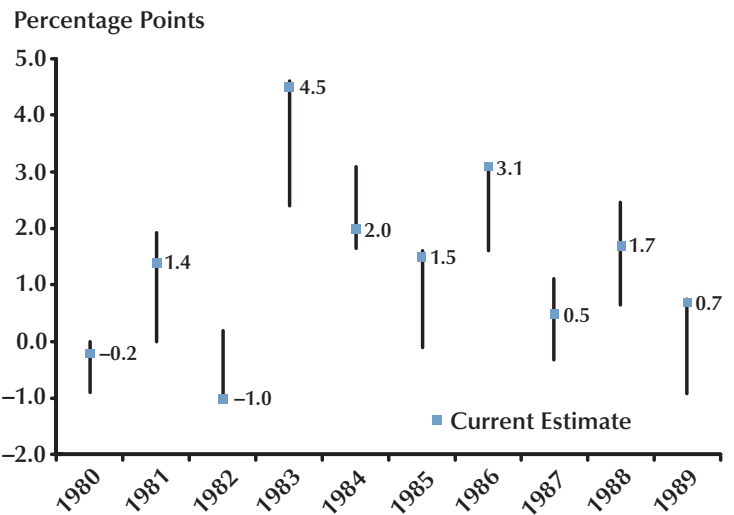

1970-79

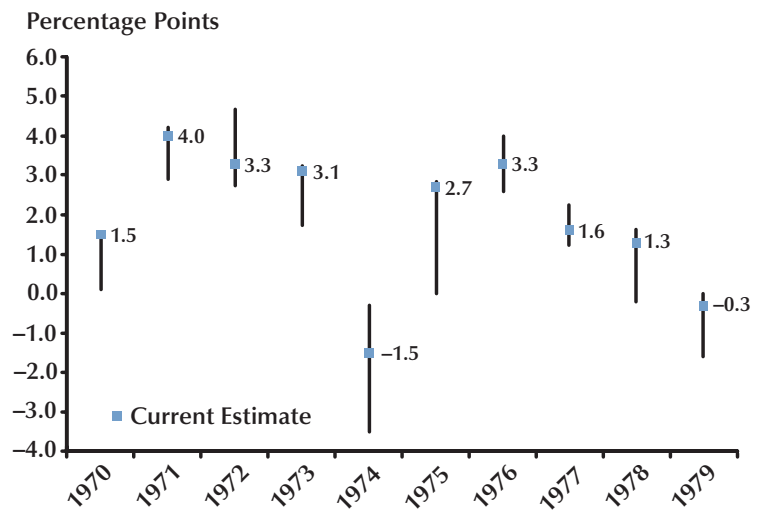

1990-2004

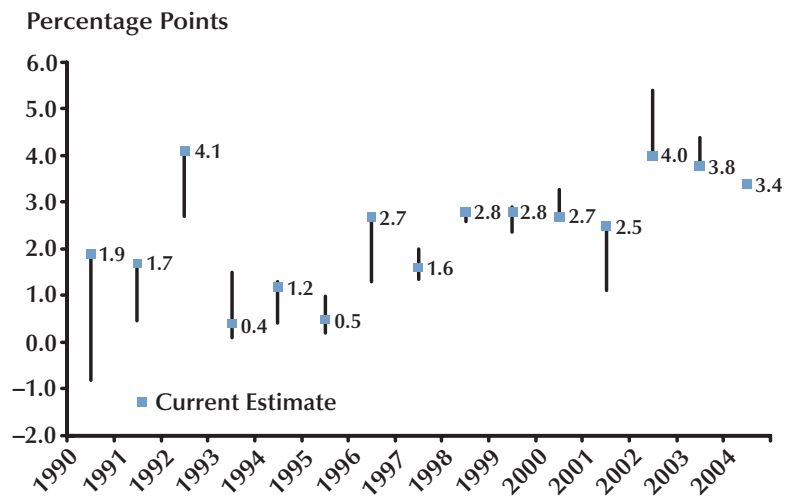

SOURCE: Economic Report of the President, annual issues, 1959-2004.

Figure 7. The revision patterns for 1995 and 1996 made it difficult to recognize, during 1995 and 1996, that a change in trend productivity growth was occurring. Although the initially published estimates for the first three quarters of 1995 suggested a productivity acceleration, by mid-1996 these estimates had been revised downward to less than 1 percent. For 1996, initial estimates for all four quarters were between approximately 0.5 and 1.5 percent, hardly supportive of acceleration. Not until the third quarter of 1997 did revised estimates sug- gest an acceleration, and not until mid-1998 was its extent clearly visible in the revised data.

Differences between first-published and most recently published productivity figures for 1985 to 2005 are summarized in Table 4 and Figures 8 and 9. The principal conclusion to be drawn from Table 4 is that, although mean revisions are small, mean absolute revisions are large, in some cases approximately equal to the estimated annual growth rate itself. Revisions to four-quarter growth rates are smaller than revisions to one-quarter growth rates, although this is due, in part, to the 
Figure 5

\section{Real-Time Estimates of 1973 Labor Productivity Growth}

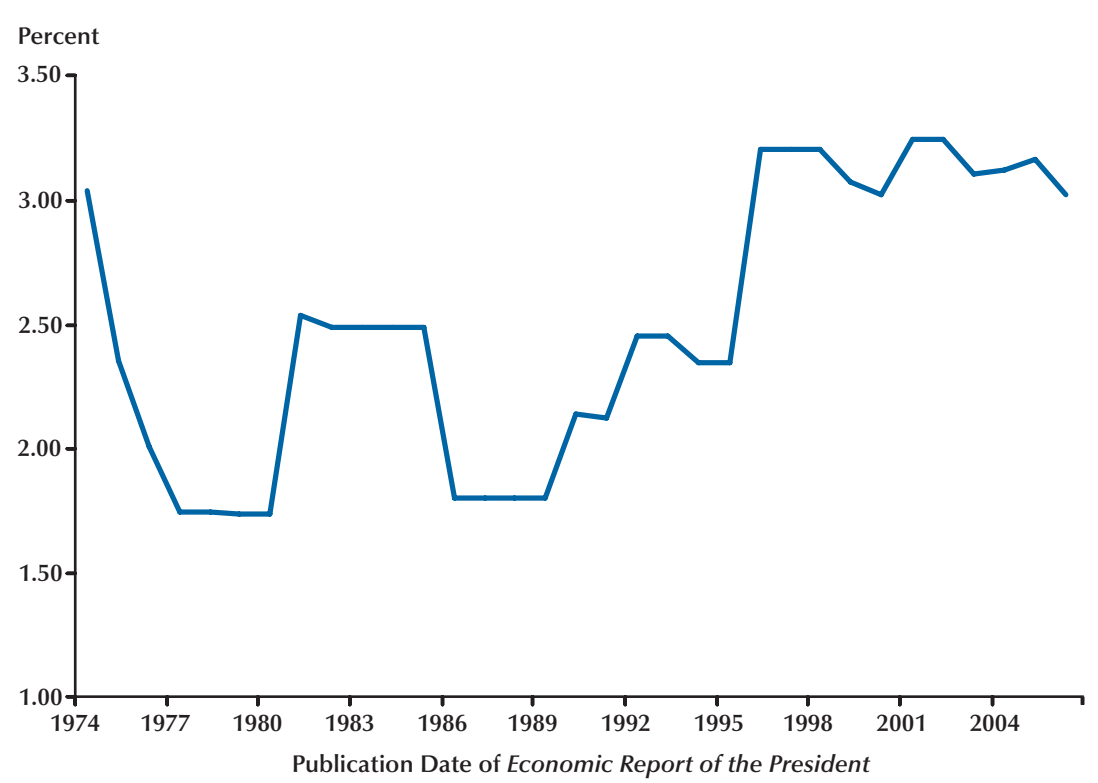

Figure 6

Labor Productivity Growth, 1995

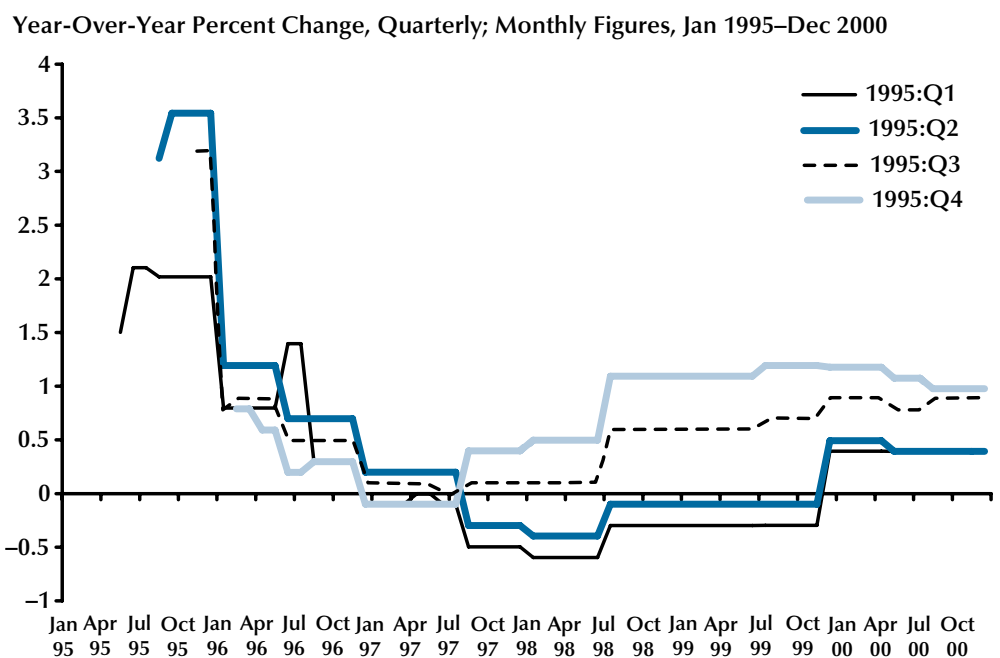


Figure 7

Labor Productivity Growth, 1996

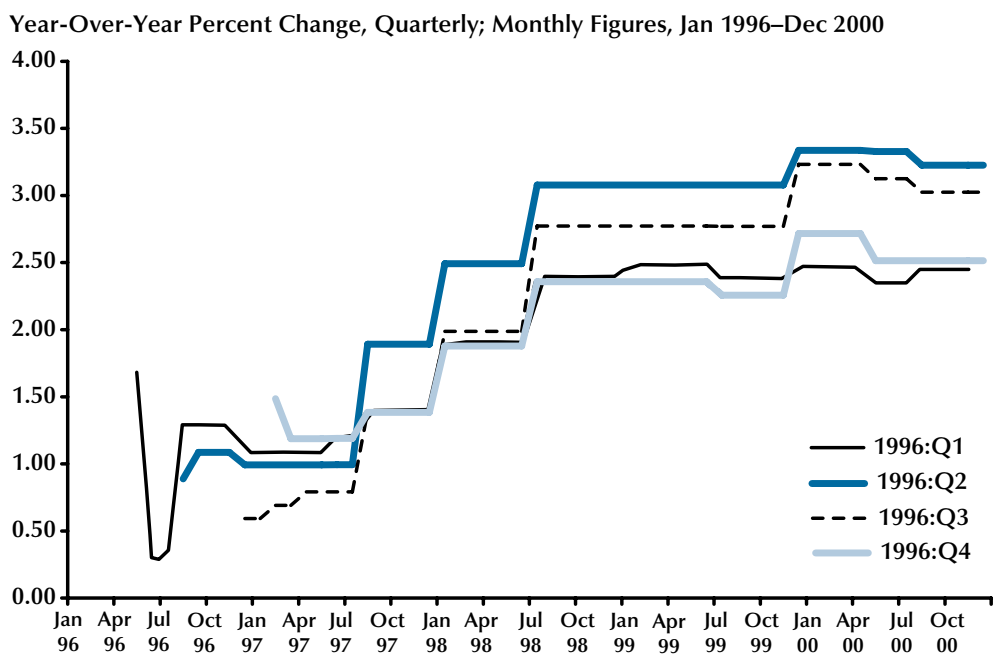

Figure 8

\section{Nonfarm Business Sector Labor Productivity Growth Estimates} (four-quarter growth rate)

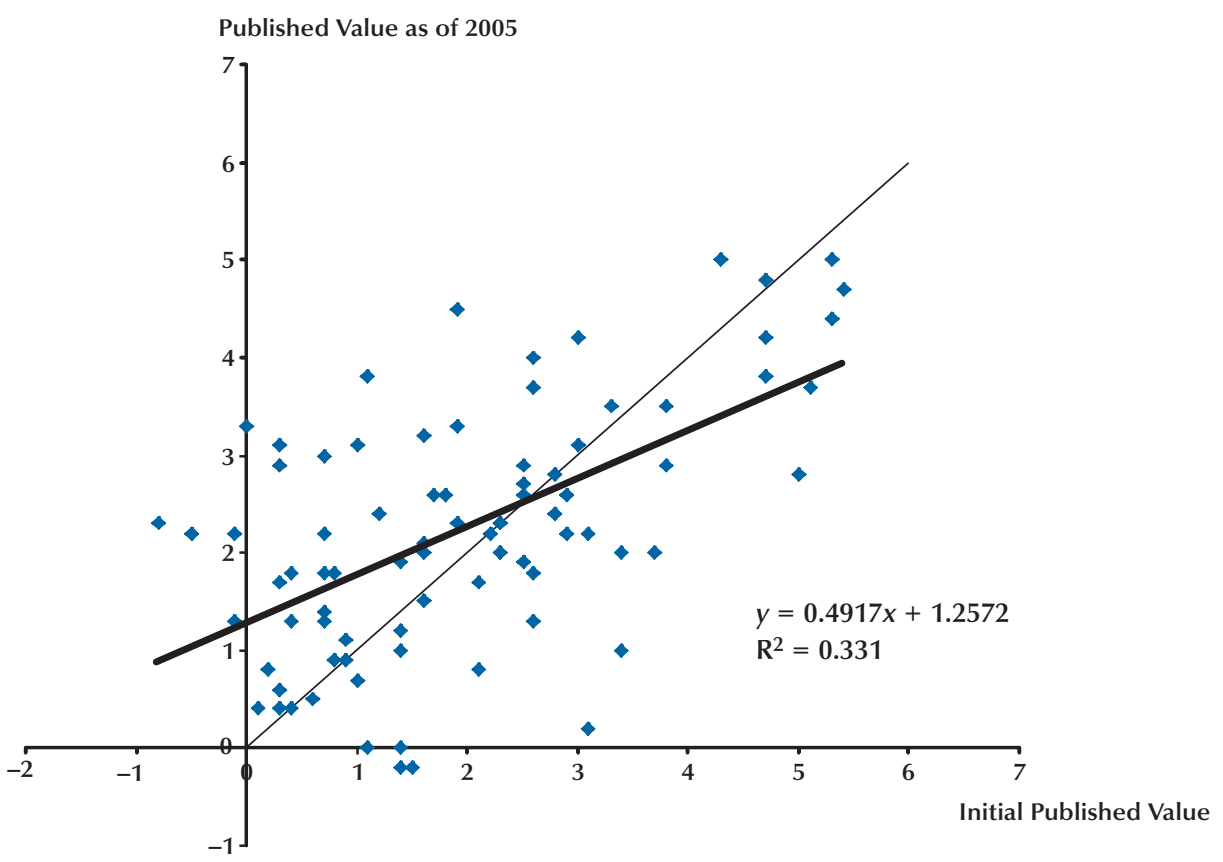


Figure 9

\section{Nonfinancial Corporate Business Labor Productivity Growth Estimates (four-quarter growth rate)}

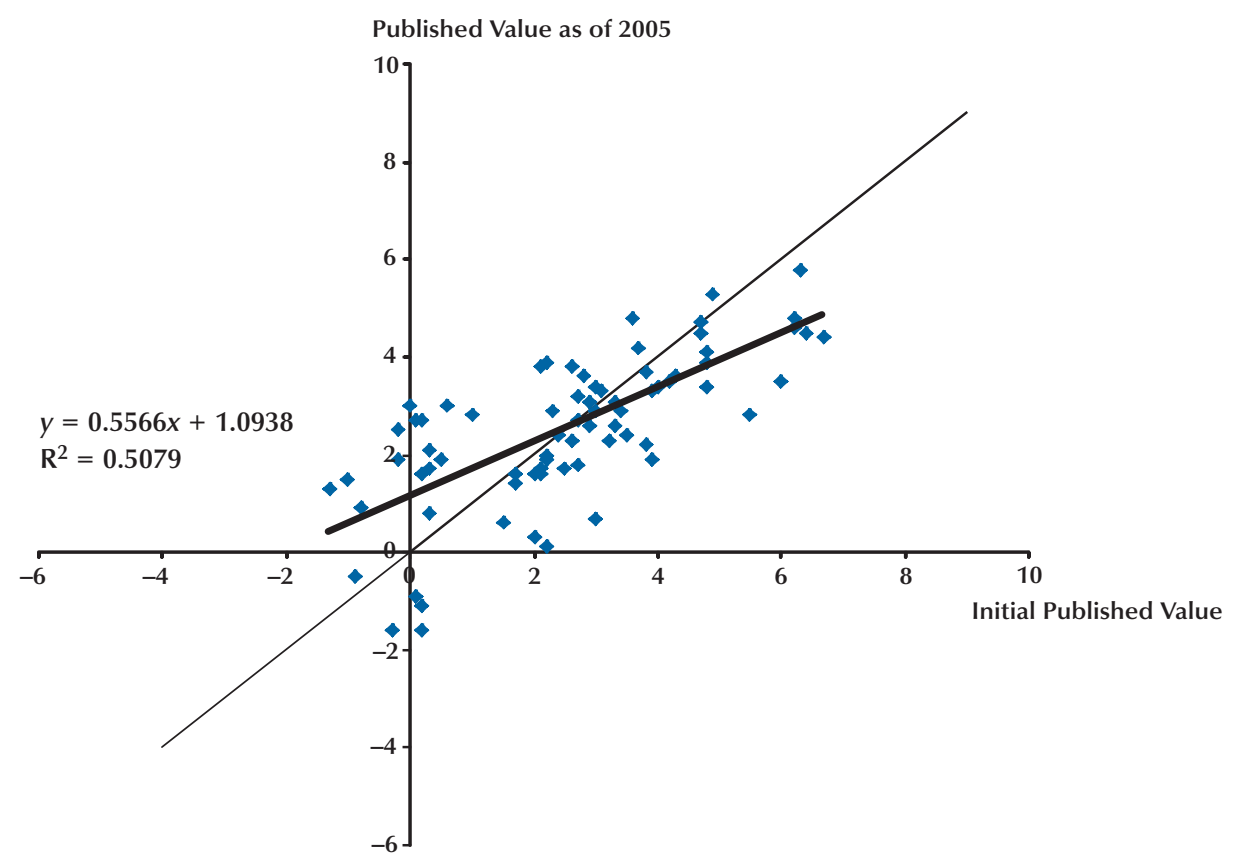

arithmetic of expressing all changes-including those for one quarter-as annualized growth rates. Note that revisions to output growth rates are smaller than those for productivity and that revisions to hours worked are smaller than revisions to output-suggesting that hours worked may be measured, at least in the near-term, with less error than output. Among the aggregate business sectors, durable goods manufacturing has the largest mean absolute revision. The larger revision likely reflects the better near-term precision with which this sector is measured, including more timely incoming revised data.

Two similar conclusions are suggested by Figures 8 and 9. First, there are large differences between first-published data and revised data. Second, more-accurate measurement matters: Revisions for the narrower and somewhat bettermeasured nonfinancial corporate business sector are smaller than for the broader and less wellmeasured nonfarm private business sector.

\section{CONCLUSIONS}

Since 1995, estimates of the economy's longrun, or structural, rate of labor productivity growth have increased significantly. After having increased at about a 1.4 percent annual rate from 1973 to 1994, the current sustainable pace of labor productivity growth in the nonfarm business sector is widely believed to be from one-half to 1 percentage point higher.

Recognition during the mid-1990s of the acceleration of productivity was delayed by weaknesses in measuring productivity. Initial aggregate data for 1995 and 1996, for example, showed little increase in measured productivity. Although these productivity measurements were at odds with both anecdotal observations at individual firms and available data on business investment spending (which suggested that rapidly falling semiconductor and computer prices were encouraging significant capital deepening), not until mid-1997 


\section{Table 4}

\section{Initially Published vs. Most Recently Published Growth Rates of Nonfarm Labor Productivity, 1985:Q3 to 2005:Q4}

\begin{tabular}{|c|c|c|c|c|c|c|}
\hline & \multicolumn{2}{|c|}{ Output per hour } & \multicolumn{2}{|c|}{ Output } & \multicolumn{2}{|c|}{ Hours } \\
\hline & $\begin{array}{l}\text { Mean } \\
\text { revision }\end{array}$ & $\begin{array}{l}\text { Mean } \\
\text { absolute } \\
\text { revision }\end{array}$ & $\begin{array}{l}\text { Mean } \\
\text { revision }\end{array}$ & $\begin{array}{l}\text { Mean } \\
\text { absolute } \\
\text { revision }\end{array}$ & $\begin{array}{l}\text { Mean } \\
\text { revision }\end{array}$ & $\begin{array}{c}\text { Mean } \\
\text { absolute } \\
\text { revision }\end{array}$ \\
\hline \multicolumn{7}{|c|}{ Growth from preceding period (quarterly, percent annual rate) } \\
\hline Business sector & 0.40 & 1.78 & 0.37 & 1.55 & -0.02 & 1.07 \\
\hline Nonfarm & 0.41 & 1.80 & 0.34 & 1.54 & -0.07 & 1.09 \\
\hline Manufacturing & 0.03 & 2.12 & -0.06 & 1.65 & -0.06 & 1.28 \\
\hline Durable & -0.08 & 2.77 & -0.04 & 2.21 & 0.05 & 1.42 \\
\hline Nondurable & 0.08 & 2.16 & -0.18 & 1.73 & -0.22 & 1.38 \\
\hline Nonfinancial corporate & -0.12 & 2.01 & -0.12 & 1.82 & -0.02 & 1.04 \\
\hline \multicolumn{7}{|c|}{ Growth from corresponding period 1 year earlier (quarterly, percent annual rate) } \\
\hline Business sector & 0.26 & 1.03 & 0.24 & 0.81 & -0.02 & 0.62 \\
\hline Nonfarm & 0.25 & 1.00 & 0.19 & 0.80 & -0.05 & 0.62 \\
\hline Manufacturing & -0.16 & 1.37 & -0.18 & 0.89 & -0.01 & 0.77 \\
\hline Durable & -0.28 & 1.89 & -0.19 & 1.43 & 0.11 & 0.83 \\
\hline Nondurable & -0.11 & 1.13 & -0.32 & 0.71 & -0.18 & 0.79 \\
\hline Nonfinancial corporate & -0.04 & 1.12 & -0.04 & 1.04 & -0.02 & 0.70 \\
\hline
\end{tabular}

NOTE: Each figure is equal to the initially published growth rate minus the most recently published growth rate for the span indicated. SOURCE: BLS, Productivity and Cost.

did revised data for 1995 and 1996 display gains in productivity growth. Our analysis suggests that such measurement delays and revisions are not uncommon.

\section{REFERENCES}

Anderson, Richard G. and Kliesen, Kevin L. "Productivity Measurement and Monetary Policymaking during the 1990s." Working Paper 2005-067, Federal Reserve Bank of St. Louis, October 2005.

Basu, Susanto; Fenald, John G.; Oulton, Nicholas and Srinivasan, Sylaja. "The Case of the Missing Productivity Growth: Or, Does Information Technology Explain Why Productivity Accelerated in the US but Not in the UK?" NBER Working Paper No. 10010, National Bureau of Economic Research,
October 2003, published in Mark Gertler and Kenneth Rogoff, eds, NBER Macroeconomics Annual, 2003. Cambridge, MA: MIT Press, 2004.

Baumol, William J. "Macroeconomics of Unbalanced Growth: The Anatomy of Urban Crisis." American Economic Review, June 1967, 57(3), pp. 415-26.

Cohen, Linda and Young, Allie. Multisourcing: Moving Beyond Outsourcing to Achieve Growth and Agility. Cambridge, MA: Harvard Business School Press, 2005.

Corrado, Carol and Lawrence, Slifman. "Decomposition of Productivity and Unit Costs." American Economic Review, May 1999, 89(2), pp. 328-32.

Dean, Edwin R. and Harper, Michael J. "The BLS Productivity Measurement Program," in Charles R. Hulten, Edwin R. Dean, and Michael J. Harper, eds., New Developments in Productivity Analysis. 


\section{Anderson and Kliesen}

Chicago: University of Chicago Press for the NBER, 2001, pp. 55-84.

Doms, Mark. "Communications Equipment: What Has Happened to Prices?" in Carol Corrado, John Haltiwanger, and Daniel Sichel, eds., Measuring Capital in the New Economy. Chicago: University of Chicago Press for the NBER, 2005, pp. 323-62.

Edge, Rochelle M.; Laubach, Thomas and Williams, John C. "Learning and Shifts in Long-Run Productivity Growth.” Working Paper 2004-21, Board of Governors of the Federal Reserve System, April 2004.

Friedman, Thomas L. The World Is Flat. New York: Farrar, Straus, and Giroux, 2005.

Gordon, Robert J. “Does the 'New Economy' Measure Up to the Great Inventions of the Past?" Journal of Economic Perspectives, 2000, 14(4), pp. 49-74.

Gordon, Robert J. "Productivity Growth and the New Economy: Comments." Brookings Papers on Economic Activity, 2002, O(2), pp. 245-53.

Gordon, Robert J. "Exploding Productivity Growth: Context, Causes and Implications." Brookings Papers on Economic Activity, 2003, O(2), pp. 207-98.

Greenwood, Jeremy; Hercowitz, Zvi and Krusell, Per. "Long-Run Implications of Investment-Specific Technological Change." American Economic Review, 1997, 87(3), pp. 342-62.

Griliches, Zvi. Output Measurement in the Service Sectors. Chicago: University of Chicago Press, 1992.

Griliches, Zvi. "Productivity, R\&D, and the Data Constraint." American Economic Review, March 1994, 84(1), pp. 1-23.

Grimm, Bruce T. "Price Indexes for Selected Semiconductors 1974-96." Survey of Current Business, February 1998, 78(2), pp. 8-24.

Gullickson, William and Harper, Michael J. "Bias in Aggregate Productivity Trends Revisited." Monthly Labor Review, March 2002, 125(3), pp. 32-40.

Haltom, Nicholas L.; Mitchell, Vanessa D. and Tallman,
Ellis W. "Payroll Employment Data: Measuring the Effects of Annual Revisions." Federal Reserve Bank of Atlanta Economic Review, Second Quarter 2005, pp. 1-23.

Himmelberg, Charles P.; Mahoney, James M.; Bang, April and Chernoff, Brian. "Recent Revisions to Corporate Profits: What We Know and When We Knew It.” Federal Reserve Bank of New York Current Issues in Economics and Finance, March 2004, 10(3), pp. 1-7.

Holdway, Mike. "An Alternative Methodology: Valuing Quality Change for Microprocessors in the PPI.” Presentation to the Advisory Committee to the Bureau of Economic Analysis, May 11, 2001.

Hulten, Charles R. "The Measurement of Capital," in Ernst R. Berndt and Jack E. Triplett, eds., Fifty Years of Economic Measurement. Chicago: University of Chicago Press for the NBER, 1990, pp. 119-52.

Hulten, Charles R. "Growth Accounting When Technical Change Is Embodied in Capital." American Economic Review, September 1992, 82(4), pp. 964-80.

Hulten, Charles R. "Total Factor Productivity: A Short Biography,” in Charles R. Hulten, Edwin R. Dean, and Michael J. Harper, eds., New Developments in Productivity Analysis. Chicago: University of Chicago Press for the NBER, 2001

Jones, Charles I. "Sources of U.S. Economic Growth in a World of Ideas." American Economic Review, March 2002, 92(1), pp. 220-39.

Jorgenson, Dale W.; Gollop, Frank M. and Fraumeni, Barbara M. Productivity and U.S. Economic Growth. Harvard Economic Studies. Volume 159. Cambridge, MA: Harvard University Press, 1987.

Jorgenson, Dale W.; Ho, Mun S. and Stiroh, Kevin J. "Projecting Productivity Growth: Lessons from the U.S. Growth Resurgence." Federal Reserve Bank of Atlanta Economic Review, Third Quarter 2002, pp. 1-13.

Jorgenson, Dale W.; Ho, Mun S. and Stiroh, Kevin J. "Lessons from the U.S. Growth Resurgence." Paper prepared for the First International Conference on the Economic and Social Implications of Information 
Technology, Washington, DC, January 27-28, 2003; www.si.umich.edu/ kahin/hawk/htdocs/ jorgensonpaper.doc.

Jorgenson, Dale W.; Ho, Mun S. and Stiroh, Kevin J. "Will the U.S. Productivity Resurgence Continue?" Federal Reserve Bank of New York Current Issues in Economics and Finance, December 2004, 10(13).

Jorgenson, Dale W.; Ho, Mun S. and Stiroh, Kevin J. "Projecting Productivity Growth: Lessons from the U.S. Growth Resurgence," in William H. Dutton et al., eds., Transforming Enterprises: The Economic and Social Implications of Information Technology. Cambridge, MA: MIT Press, 2005, pp. 49-75.

Jorgenson, Dale W.; Landefeld, J. Steven and Nordhaus, William D. A New Architecture for the U.S. National Accounts. Chicago: University of Chicago Press for the NBER, 2006 (forthcoming).

Kozicki, Sharon. "The Productivity Growth Slowdown: Diverging Trends in the Manufacturing and Service Sectors.” Federal Reserve Bank of Kansas City Economic Review, First Quarter 1997, pp. 31-46.

Kozicki, Sharon. "How Do Data Revisions Affect the Evaluation and Conduct of Monetary Policy?" Federal Reserve Bank of Kansas City Economic Review, First Quarter 2004, 89(1), pp. 5-38.

Landefeld, J. Steven and Grimm, Bruce T. "A Note on the Impact of Hedonics and Computers on Real GDP." Survey of Current Business, December 2000, pp. 17-22.

Oliner, Stephen D. and Sichel, Daniel E. "Information Technology and Productivity: Where Are We Now and Where Are We Going?" Federal Reserve Bank of Atlanta Economic Review, Third Quarter 2002, 87(2), pp. 1-13.

Orphanides, Athanasios and van Norden, Simon. "The Reliability of Inflation Forecasts Based on Output Gap Estimates in Real Time." Journal of Money, Credit, and Banking, June 2005, 37(3), pp. 583-601.

Pakko, Michael R. "The High-Tech Investment Boom and Economic Growth in the 1990s: Accounting for Quality.” Federal Reserve Bank of St. Louis Review, March/April 2002a, 84(2), pp. 3-18.

Pakko, Michael R. "What Happens When the Technology Growth Trend Changes? Transition Dynamics, Capital Growth and the 'New Economy'." Review of Economic Dynamics, April 2002b, 5(2), pp. 376-407.

Pakko, Michael R. "Changing Technology Trends, Transition Dynamics, and Growth Accounting." Contributions to Macroeconomics, 2005, 5(1), Article 12.

Runkle, David E. "Revisionist History: How Data Revisions Distort Economic Policy Research." Federal Reserve Bank of Minneapolis Quarterly Review, Fall 1998, 22(4), pp. 3-12.

Sherwood, Mark K. "Difficulties in the Measurement of Service Outputs." Monthly Labor Review, March 1994, 117(3), pp. 11-19.

Solow, Robert. "Technical Change and the Aggregate Production Function." Review of Economics and Statistics, 1957, 39(3), pp. 312-20.

Solow, Robert. "Investment and Technological Progress," in Kenneth Arrow, Samuel Karlin, and Patrick Suppes, eds., Mathematical Methods in the Social Sciences. Stanford, CA: Stanford University Press, 1960, pp. 89-104.

Solow, Robert. "After 'Technical Progress and the Aggregate Production Function'," in Charles R. Hulten, Edwin R. Dean, and Michael J. Harper, eds., New Developments in Productivity Analysis. Chicago: University of Chicago Press for the NBER, 2001, pp.173-78.

Stiroh, Kevin J. "Information Technology and the U.S. Productivity Revival: What Do the Industry Data Say?" American Economic Review, December 2002, 92(5), pp. 1559-76.

Triplett, Jack E. and Bosworth, Barry P. "Productivity in the Services Sector," in Robert M. Stern, ed., Services in the International Economy. Ann Arbor, MI: University of Michigan Press, 2001; www.brookings.edu/views/papers/triplett/ 20000112.htm. 


\section{Anderson and Kliesen}

Triplett, Jack E. and Bosworth, Barry P. "Productivity Measurement Issues in Services Industries: 'Baumol's Disease' Has Been Cured.” Federal Reserve Bank of New York Economic Policy Review, September 2003, 9(3), pp. 23-33.

Triplett, Jack E. and Bosworth, Barry P. Productivity in the U.S. Services Sector. Washington, DC: Brookings Institution, 2004.

Triplett, Jack E. and Bosworth, Barry P. "Baumol's Disease Has Been Cured: IT and Multifactor Productivity Growth in the U.S. Services Industries," in Dennis Jansen, ed., The New Economy and Beyond: Past, Present and Future. Cheltenham: Edward Elgar, 2006 (forthcoming); www.brookings.edu/es/research/projects/ productivity/workshops/20020517_triplett.pdf.

Yuskavage, Robert E. "Improved Estimates of Gross Product by Industry, 1959-94." Survey of Current Business, August 1996, 76(8), pp. 133-55.

Yuskavage, Robert E. and Pho, Yvon H. "Gross Domestic Product by Industry for 1987-2000.” Survey of Current Business, November 2004, pp. 33-53. 